principle of scientific and pedagogical search. The theoretical and comparative analysis was based on the analysis of Polish legislative documents in the education field.

The article describes the school system in Poland, which functions after the introduced educational reform in 2016. It is determined that in the school education system in Poland there was an introduction of an 8-year elementary or basic school, instead of a 6-year school and a gymnasium (3 years); 3-year general education lyceums became 4-year lyceums (general secondary), and 4-year technical schools - 5-year technical schools, as well as two levels of vocational schools. The author raises the question of the justification for the liquidation of a gymnasium at the school education level. It was noted that it will be possible to assess the feasibility and effectiveness of the school education reform in Poland only after conducting appropriate independent monitoring.

The analysis and comparison of structural changes that occurred as a result of the education reform in 1999 and 2016 are presented. It was analyzed in detail, introduced in 1999 gymnasium level of school education. In particular, it was noted that educational reforms that took place in Poland in different years, along with changes in the education structure, were aimed at improving quality and promoting equal access to education. These educational changes can be defined as planned and systemic.

The author concludes that modern education reform is aimed at improving the quality and accessibility of education, digital competencies of both students and teachers, at improving inclusive education, digitalization of school education. Structural, organizational and curriculum changes that have taken place in the education system of Poland are in line with global trends and serve to further improve the quality of educational services.

Further research requires the issue of the effectiveness of reforms, taking into account the requirements of the time, in particular, the relationship between education and the labor market in the aspect of the educational policy formation in the long term.

Key words: gymnasium, digitalization of school education, modernization of the educational content, Republic of Poland, education reform, equal access to education, school system of Poland.

UDC 378.6:61(73)]:616-071:005.342

\author{
Alla Kulichenko \\ Zaporizhzhia State M edical University \\ Sumy State Pedagogical University Named after A. S. Makarenko \\ ORCID ID 0000-0003-1469-3816 \\ Maryna Boichenko \\ Sumy State Pedagogical University Named after A. S. Makarenko \\ ORCID ID 0000-0002-0543-8832 \\ DOI 10.24139/2312-5993/2020.07/240-250
}

\title{
CLINICAL RESEARCH IN THE MEDICAL COLLEGES OF U.S. UNIVERSITIES: INNOVATION TRENDS
}

The article reveals innovation trends and their features during clinical trials in medical colleges of U.S. universities. The authors have found that clinical research deals with developing 
and implementing innovative products, tools, technologies, and equipment for quality medical care, treatment, and disease prevention. Clinical research focuses on observational studies and clinical trials. Note that in clinical trials global innovation trends include patient-centeredness; ensuring the protection of information within e-health; development of mobile healthcare technologies; automation of materials for clinical trials; cybersecurity priority.

Key words American medical colleges, medical education, research, innovation trends, features, clinical research, observational studies, clinical trials.

Introduction. At present, clinical research attracts the attention of people all over the world. Therefore, American medical colleges, given this trend, provide the opportunity for anyone who wishes to obtain a master's degree in clinical research. The training lasts from 12 to 24 months, during which one studies the theory and practice of clinical trials, their specific features, connection with the challenges of modern society, and comprehends innovation directions. A. Thajer et al. states that "clinical research is an important pillar of evidence-based medicine, which combines individual clinical expertise with the best available external clinical evidence from systematic research to support medical decisions" (Thajer et al., 2020).

Analysis of relevant research. The problem of clinical research in the medical colleges of the U.S. universities is relevant for the English-speaking scientific space. State websites of such organizations as The U.S. Food and Drug Administration (https://www.fda.gov), the U.S. Department of Health and Human Services (www.nia.nih.gov), etc., deal with American clinical research. E. Ahrens, K. Mackenzie, O. Morgan, M. Ruf, R. Sacco, A. Thajer, and others focus on opportunities, pros and cons of clinical research. E. Campbell, J. Cohen, K. Meador, D. Zinner, and others consider the importance of clinical research in the U.S. academic medical centers and medical colleges. S. Ahmad, K. Sookne, J. Whyte point to prospects of clinical trials.

However, this issue needs to be covered in detail in domestic pedagogy to implement the best American practices in Ukrainian higher medical educational establishments.

The study aims to highlight innovation trends and specify their features in the context of clinical research in the medical colleges of U.S. universities.

Research methods. To achieve the aim of the study, we have chosen the following methods: analysis, synthesis, systematization, and generalization of references on the issue of clinical research in the medical colleges of the U.S. universities. Besides, there is a structural and logical method - to classify clinical research and to determine innovation trends, their features.

Results. Clinical research is one of the core areas of innovation in the medical colleges of U.S. universities. It aims at developing and implementing 
innovative products, tools, technologies, and equipment for quality health care, treatment, and prevention of diseases, etc. A. Thajer et al. argue that "clinical research, therefore, plays an important role with regard to the request for standardized clinical decision-making" (A. Thajer et al., 2020).

According to the U.S. Department of Health and Human Services, clinical research is medical research involving human beings. There are two types of clinical research - observational studies and clinical trials (What is..., 2020).

Observational studies involve observing people within normal conditions. Researchers gather information (for example, medical examinations, tests, or questionnaires), group volunteers due to different characteristics, and compare changes over time (What is..., 2020).

Clinical trials are scientific studies performed on humans to evaluate medical, surgical, or behavioral interventions (What is..., 2020). According to the definition provided by the National Institutes of Health $(\mathrm{NIH})$, a clinical trial is a study in which one or more human beings are involved in one or some interventions (which may include placebo or other control) to assess their impact on biomedical or behavioral outcomes related to health status (Clinical Trials, n.d.). Clinical trials determine the safety of humans and the effectiveness of a new treatment, drug, diet, or medical equipment. Besides, clinical trials may focus on ways to detect the disease early (for example, before symptoms appear), or to prevent health problems. One of the areas of clinical trials is to improve the lives of people with chronic diseases or life-threatening conditions.

The classification of clinical trials by the U.S. National Institutes of Health is presented in Fig.1.

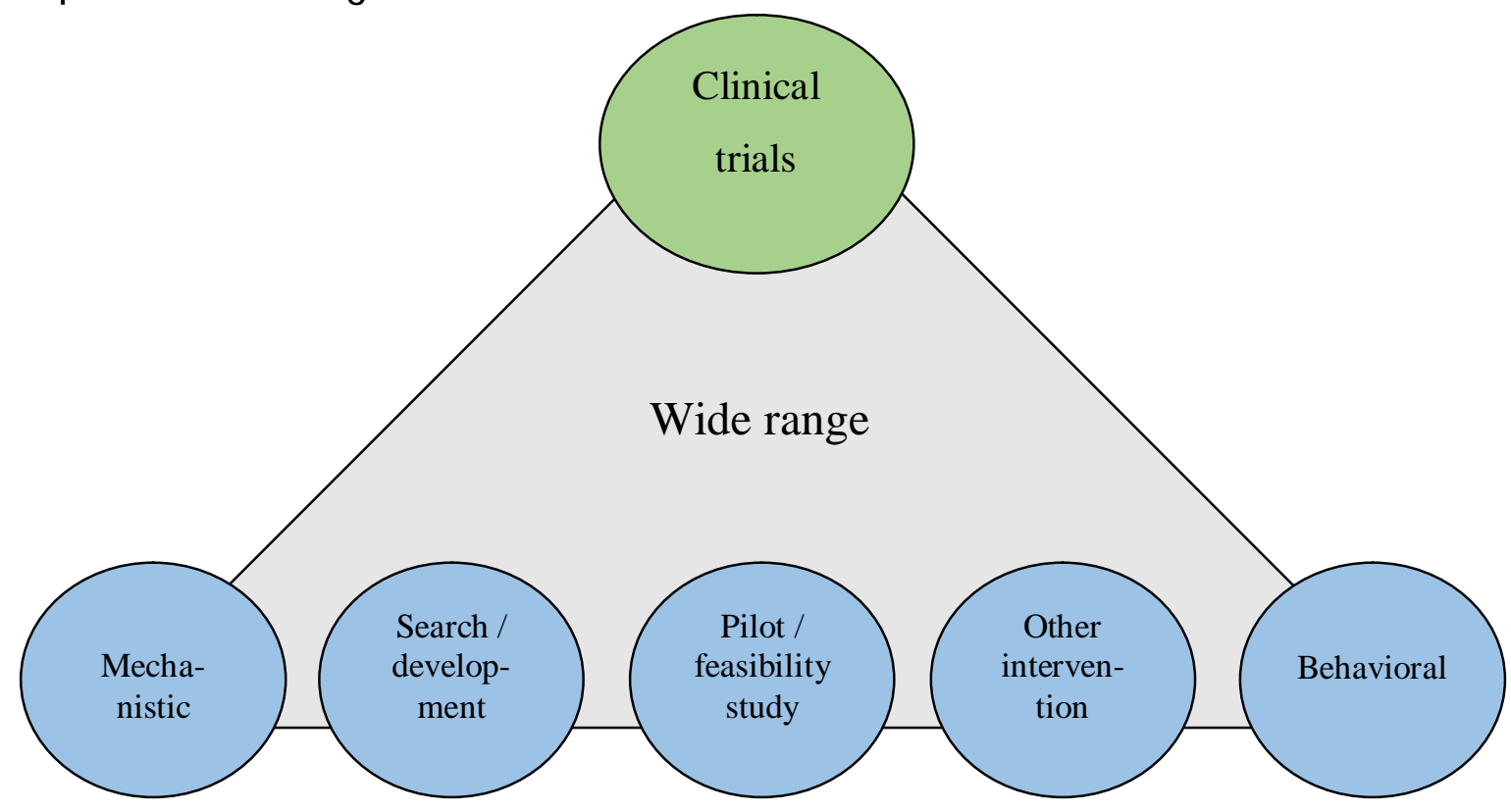

Fig. 1. Classification of clinical trials (Clinical Trials, n.d.). 
Note that permission for clinical trials in the United States is granted by the U.S. Food and Drug Administration (FDA) after laboratory and animal studies have shown positive results and demonstrated the potential safety and efficacy of therapy (What Are the Different..., 2018).

This organization identifies the following types of clinical trials:

- treatment research usually involves intervention (medical, psychotherapeutic, use of new devices or new approaches) (surgery, radiation therapy, etc.);

- prevention research is aimed at finding the best ways to prevent the development or resurgence of diseases. Different types of prevention research can study drugs, vitamins, vaccines, minerals, or lifestyle changes;

- diagnostic research refers to finding the best ways to identify a disorder or condition;

- screening research aims to find the best ways to detect certain disorders or health conditions, usually in the early stages;

- quality of life research involves finding ways to improve the level of comfort and quality of life of people with chronic diseases;

- the genetic study deals with improvement of the disease prediction by identifying and understanding how genes and diseases can be linked, as well as developing specific treatments based on the patient's genetic predispositions;

- the epidemiological study aims at identifying patterns, causes, and control of disorders in groups of people (What Are the Different..., 2018).

Since screening and diagnostic studies have a common goal, we will consider these types in more detail. In this context, the comparative characteristics of these types of clinical trials by M. Ruf and O. Morgan (2008), modified by K. M ackenzie (2017), deserve attention.

According to researchers, the main purpose of the screening study is to identify the disease at an early stage or risk factors for the disease in many hypothetically healthy people. Instead, the purpose of the diagnostic study is to establish the presence (or absence) of the disease as a basis for deciding on treatment in symptomatic or screening-positive individuals (confirmatory test) (Ruf \& M organ, 2008; Mackenzie, 2017). The main differences between these types of research are mentioned in the Table 1.

Typically, clinical trials have four phases. After the first three phases, if researchers decide on the safety and efficacy of a drug or other intervention, the FDA approves it for clinical use and continues to monitor its effects. Clinical trials of drugs are usually described based on their phase. There are the following phases: 


\section{Differences between diagnostic and screening studies}

(Ruf \& M organ, 2008; M ackenzie, 2017).

\begin{tabular}{|c|c|c|}
\hline & Screening study & Diagnostic study \\
\hline Goal & $\begin{array}{l}\text { To identify indicators (symptoms) } \\
\text { of potential disease }\end{array}$ & $\begin{array}{l}\text { To identify the presence/absence of } \\
\text { disease }\end{array}$ \\
\hline Target Group & $\begin{array}{l}\text { A large group of people who have } \\
\text { no symptoms of the disease but } \\
\text { are at risk }\end{array}$ & $\begin{array}{l}\text { People with certain symptoms for } \\
\text { diagnosis and people who have no } \\
\text { symptoms but have positive } \\
\text { screening results }\end{array}$ \\
\hline $\begin{array}{l}\text { Testing } \\
\text { Method }\end{array}$ & $\begin{array}{l}\text { Simple, acceptable for patients and } \\
\text { medical staff }\end{array}$ & $\begin{array}{l}\text { It may be invasive, expensive, but } \\
\text { justified if it is necessary for a } \\
\text { diagnosis }\end{array}$ \\
\hline $\begin{array}{l}\text { Threshold of } \\
\text { Positive } \\
\text { Result }\end{array}$ & $\begin{array}{l}\text { High sensitivity is preferred not to } \\
\text { miss a potential illness }\end{array}$ & $\begin{array}{l}\text { Accuracy is preferred over patient } \\
\text { acceptability }\end{array}$ \\
\hline $\begin{array}{l}\text { Positive } \\
\text { Result }\end{array}$ & $\begin{array}{l}\text { It indicates a suspicion of the } \\
\text { disease (often used in combination } \\
\text { with other risk factors), which } \\
\text { requires confirmation }\end{array}$ & The result gives a clear diagnosis \\
\hline Cost & $\begin{array}{l}\text { Low cost, benefits should justify } \\
\text { the cost, as many people will need } \\
\text { to be tested to identify a few } \\
\text { potential cases }\end{array}$ & $\begin{array}{l}\text { Higher costs associated with the } \\
\text { diagnostic procedure may be } \\
\text { justified for diagnosis }\end{array}$ \\
\hline
\end{tabular}

- as part of phase I, a small group of often healthy people (20 to 80 ) is experimentally treated to assess its safety, identify side effects, and determine the correct dose;

- more people (from 100 to 300) are involved in phase II. If within phase I an emphasis is on safety, then within phase II it is on efficiency. This phase aims to obtain preliminary data on the drug effectiveness in persons with a certain disease or condition. These trials also continue to study safety, including short-term side effects. Phase II can last for several years;

- phase III gathers more information on safety and efficacy by studying different populations and different dosages using the drug in combination with other drugs. The number of subjects usually ranges from a few hundred to about 3,000 people. If the FDA agrees with the positive test results, it will approve the experimental drug or device;

- phase IV deals with the test of drugs or devices. It starts after the FDA has authorized them. The effectiveness and safety of the device or drugs are 
monitored during their use by many people. Sometimes the side effects of the drug are detected when more people take it for a long period (What Are the Different..., 2018; What is..., 2020).

Considering clinical research as a direction of innovation activity in medical colleges of American universities, we will highlight the following global innovation trends within the development of clinical trials: patientcenteredness; ensuring the protection of information in the electronic health care system; development of mobile healthcare technologies; automation of materials for clinical trials; cybersecurity priority, etc.

Patient-centeredness assumes that participants are active during the trial but not just the objects of the study. The innovation of the trend is that the core indicator is transparency, i.e. obtaining maximum information from patients about the nature of the test, its course, and consequences. In addition to transparency, patient-centeredness also includes the use of an individual approach to increase participation in clinical trials. The FDA insists on increasing the representativeness of clinical trials, which should reflect the diversity of American society (Whyte, 2017).

Ensuring information protection within the electronic health care system (eHealth). On the one hand, increasing transparency implies free open access to the results of clinical trials, which requires the creation of new and improvement of existing storage platforms. On the other hand, there is the need to develop mechanisms to protect the personal data of trial participants posted on appropriate platforms.

Development of mobile healthcare technologies (mHealth). Today the number of clinical trials to test the safety and effectiveness of mobile health technologies is increasing. By mobile health technologies, we mean the use of mobile devices and wireless technologies to provide medical care as well as to ensure a healthy lifestyle. As for examples of such technologies, there are applications for mobile phones and tablets related to physical fitness (weight, heart rate, etc.) and fitness.

The mHealth system was one of the first such technologies in the world. It was developed in 2005 at the University of London under the leadership of professor B. Woodward in cooperation with Indian scientists. The unique system allows a person to monitor human health and transfer data from a mobile phone to a clinic anywhere in the world. This device could transmit data on blood oxygen saturation, blood pressure, blood glucose, heart rate to any clinic in the world.

In July 2017, the Center for Devices and Radiological Health in the USA (the FDA Unit) released the Digital Health Innovation Action Plan, which 
included detailed steps to implement a digital health strategy aimed at providing all Americans with timely access to high-quality, safe and effective digital health products. The use of digital health technologies, according to the develo pers of the outlined Plan, will increase the efficiency of medical services; expand access to medical services; reduce costs; improve the quality of medical services; personalize medical services for patients (FDA issues digital..., 2020).

Researchers also point out that patients and consumers can use digital health technologies to better manage and track their health activities. After all, the use of technologies such as smartphones, social networks, and Internet applications leads to the convergence of people, information, technology, and connections to improve health and health outcomes (What is Digital..., 2020).

Numerous modern medical devices can connect to and interact with other devices or systems. Devices, approved by the FDA, are updated to add digital features. The following new types of devices are subject to clinical trials:

- artificial intelligence and machine learning in software as a medical device;

- cybersecurity;

- device software features, including mobile medical applications;

- health-saving IT;

- medical device data systems;

- compatibility of medical devices;

- Software as a M edical Device (SaMD);

- telemedicine;

- wireless medical devices (What is Digital..., 2020).

Within the framework of this trend, the main goal is to introduce mobile healthcare technologies in the activities of health care providers. In this context, S. Ahmad's opinion (Ahmad, 2020) is topical concerning the prospects of their use. There are such statements:

- remote monitoring of the patient. Devices for remote monitoring of the patient monitor the patient's condition and send the relevant data to the medical worker via electronic media. The data monitors sleep patterns, heart rate, exercises, such as steps, glucose levels, blood test results, and medical images (such as an ECG, etc.);

- involvement of tablets and smartphones to communicate with medical staff. At present, most doctors use phone calls to stay in touch with their patients and monitor their health and current condition. At the same time, considering the popularity of tablets and smartphones among the population, the developers of mHealth programs are actively creating services available to both patients and doctors; 
- Big Data. The distribution of mobile healthcare has necessitated the accumulation of large amounts of user data known as Big Data. Big Data is used for the electronic health record (EHR). Their further use, according to S. Ahmad, will reduce the cost of treatment; improve the process of patient care and preventive care; improve the quality of life; reduce the waiting time for medical service/doctor's appointment; personalize treatment; increase the level of security;

- integration of the Internet of Things (IOT) and artificial intelligence. These technologies are among the leading ones on the market. IOT devices allow a patient to receive timely medical attention during emergencies. An example of the IOT is the use of portable glucose monitors, which facilitate the doctor's diagnosis of the patient and increase the accuracy of treatment. Similarly, artificial intelligence helps devices learn, respond, feel, and understand in a way that it can perform various administrative and medical functions of the health care system. MHealth software that uses artificial intelligence includes virtual nurses' assistants; program to reduce the dosage of the drug; program for preliminary diagnosis; cybersecurity of mHealth programs;

- the use of augmented and virtual reality. It allows patients in a comfortable environment to view videos of virtual reality for therapeutic purposes. The integration of these programs with wearable devices is aimed at managing patient care in the hospital or at home;

- the use of predictive analysis. It allows medical staff to personalize patient care. Currently, the United States uses mHealth predictive analysis technologies such as geo-mapping, risk estimation, and what-if cases to prevent deterioration in patients' health, save patients from self-harm, etc. (Ahmad, 2020).

Automation of materials for clinical trials. The annual increase in the market for consumables for clinical trials, which experts estimate (Sookne, 2017), is $5 \%$. Thus, the issue of automation of materials for clinical trials is relevant to increase their efficiency and save valuable resources. It is an indisputable fact that the complexity of modern clinical trials increases exponentially if different countries are involved.

Cybersecurity priority. The issue of data security during clinical trials is particularly crucial, due to both the value of the innovative product and the protection of personal data. One solution is to use innovative encryption methods, such as Blockchain, to securely and share data and secure access to clinical trial information.

However, K. Meador emphasizes that "national health care research funding policies should encourage the right balance of life-science investigations. Medical universities need to improve and highlight education on clinical research 
for students, residents, fellows, and young faculty. Medical universities also need to provide appropriate incentives for clinical research. Without training to ensure an adequate supply of skilled clinical researchers and a method to adequately fund clinical research, discoveries from basic and translational research cannot be clinically tested and affect patient care" (M eador, 2015).

Conclusions. Thus, clinical research combines both theory and practice in the medical colleges of U.S. universities. It includes observational studies and clinical trials that may be mechanistic, behavioral, pilot ones, etc. There are the following types of clinical trials: treatment research; prevention research; diagnostic research; screening research; quality of life research; genetic study; epidemiological study.

As for innovation trends within clinical trials, they include patientcenteredness; ensuring the protection of information within e-health; development of mobile healthcare technologies; automation of materials for clinical trials; cybersecurity priority. We can state that these innovation trends characterize the current state and the near future of clinical trials as a direction of innovation activity of research institutions, pharmaceutical companies, medical institutions of higher education in the USA. As for the future studies, we are going to consider in detail clinical trials of some medical colleges of the U.S. universities.

\section{REFERENCES}

Ahmad, S. (2020). Wearable Devices With mHealth Apps: Integration And Implementation. Retrieved from: https://mobisoftinfotech.com/resources/blog/mhealth-wearabledevices/.

Clinical Trials. (n.d.). osp.od.nih.gov. Retrieved from: https://osp.od.nih.gov/clinicalresearch/clinical-trials/.

FDA issues digital health innovation action plan. (2020). Medical Systems Consulting. Retrieved from: https://www.medsyscon.com/en/blog-fdaplan/\#. r.text=0n\%20M arch\%2026\%2C\%202020\%2C\%20the,and\%20effective\%20digi tal\%20health\%20products.

Meador, K.J. (2015). Decline of clinical research in academic medical centers. Neurology, 85(13), 1171-1176. DOI: 10.1212/WNL.0000000000001818.

Ruf, M. \& Morgan, O. (2008), Mackenzie, K. (2017). 2c - Diagnosis and Screening. Differences between screening and diagnostic tests and case finding. Health Knowledge. Retrieved from: https://www.healthknowledge.org.uk/public-healthtextbook/disease-causation-diagnostic/2c-diagnosis-screening/.

Sookne, K. (2017). Survey reveals current and future trends in clinical trial supplies market. Healthcare Packaging Magazine. Retrieved from: https://www.healthcarepackaging.com/home/news/14215729/survey-revealscurrent-and-future-trends-in-clinical-trial-supplies-market.

Thajer, A., Sommersguter-Reichmann, M. \& Löffler-Stastka, H. (2020). Implementing a Clinical Research Department to Support Pediatric Studies: A SWOT Analysis. International Journal of Environmental Research and Public Health, 17, 6211. DOI:10.3390/ijerph17176211. 
Педагогічні науки: теорія, історія, інноваційні технології, 2020, № 7 (101)

What Are Clinical Trials and Studies? (n.d.). www.nia.nih.gov. Retrieved from: https:// www .nia.nih.gov/health/what-are-clinical-trials-and-studies.

What Are the Different Types of Clinical Research? (2018). www.fda.gov. Retrieved from: https:// www.fda.gov/patients/clinical-trials-what-patients-need-know/what-aredifferent-types-clinical-research.

What is Digital Health? (2020). www.fda.gov. Retrieved from: https://www.fda.gov/medicaldevices/ digital-health-center-excellence/what-digital-health.

Whyte, J. J. (2017). An FDA Perspective on Patient Diversity in Clinical Trials. Clinical Leader. Retrieved from: https://www.clinicalleader.com/doc/an-fda-perspective-on-patientdiversity-in-clinical-trials-0001.

\section{АНОТАЦІЯ}

Куліченко Алла, Бойченко Марина. Клінічні дослідження в діяльності медичних коледжів університетів США: інноваційні тенденції.

Статтю присвячено висвітленню інноваційних тенденцій та виокремленню їх особливостей під час клінічних досліджень у діяльності медичних коледжів університетів США.

Для досягнення мети розвідки використано такі методи: аналіз, синтез, систематизація та узагальнення джерел із питання клінічних досліджень у медичних коледжах університетів США. Крім того, було застосовано структурно-логічний метод - для подання класифікації клінічних досліджень і визначення інновачійних тенденцій та їх особливостей.

З'ясовано, що клінічні дослідження спрямовані на розробку й упровадження інновачійних продуктів, засобів, технологій та обладнання для якісного медичного обслуговування, лікування і профілактики захворювань тощо. Установлено, що до клінічних досліджень належать обсерваційні дослідження (спостереження за людьми у звичайних умовах) та клінічні випробування (наукові дослідження, проведені на людях $і$ спрямовані на оцінку медичного, хірургічного або поведінкового втручання). Крім того, у статті наведено такі типи клінічних випробувань, як лікувальне дослідження, профрілактичне дослідження, діагностичне дослідження, скринінгове дослідження, дослідження якості життя, генетичне дослідження, епідеміологічне дослідження.

Розглядаючи клінічні дослідження як напрям інноваційної діяльності медичних коледжів університетів США, автори статті визначили інноваційні тенденції розвитку клінічних випробувань, а саме: пацієнтоцентризм; забезпечення захисту інформації в межах електронної системи охорони здоров'я; розвиток мобільних технологій охорони здоров'я; автоматизація матеріалів для клінічних випробувань; пріоритет кібербезпеки. Зазначені інноваційні тенденції характеризують сучасний стан $і$ найближче майбутнє клінічних випробувань як напряму інноваційної діяльності науководослідних установ, фрармацевтичних компаній, медичних закладів вищої освіти тощо. що стосується перспектив подальших досліджень, то актуальним $\epsilon$ детальний розгляд клінічних досліджень в окремих медичних коледжах університетів США.

Ключові слова: американські медичні коледжі, медична освіта, дослідження, інноваційні тенденції, особливості, клінічні дослідження, обсерваційні дослідження, клінічні випробування. 


\title{
PEЗЮME
}

Куличенко Алла, Бойченко Марина. Клинические исследования в деятельности медицинских колледжей университетов США: инновационные тенденции.

Статья посвящена изучению инновационных тенденций, выделению их особенностей во время клинических исследований в медицинских колледжах университетов США. Выяснено, что клинические исследования направлены на разработку и внедрение инновационных продуктов, средств, технологий и оборудования для качественного медицинского обслуживания, лечения и профилактики заболеваний. $K$ глобальным инновационным тенденциям развития клинических испытаний относятся такие: пациентоцентризм; обеспечение защиты информации в пределах электронной системы здравоохранения; развитие мобильных технологий здравоохранения; автоматизация материалов для клинических испытаний; приоритет кибербезопасности.

Ключевые слова: американские медицинские колледжи, медицинское образование, исследование, инновационные тенденции, особенности, клинические исследования, обсервационные исследования, клинические испытания.

\section{удк 376.011.3-051}

\author{
Наталія Никоненко \\ Національний педагогічний університет \\ імені М. П. Драгоманова \\ ORCID ID 0000-0002-0277-9113 \\ DOI 10.24139/2312-5993/2020.07/250-263
}

\section{ЕВОЛЮЦІЯ СТАНДАРТІВ ПІДГОТОВКИ КВАЛІФІКОВАНОГО ВЧИТЕЛЯ СПЕЦІАЛЬНОÏ ОСВІТИ У США}

Дослідження американського досвіду в підготовці вчителів спеціальної освіти передбачає історичний і компаративний аналіз відповідних стандартів. У результаті аналізу зроблено висновки про залежність стандартів підготовки спеціальних учителів від суспільно-політичних, економічних та інших чинників, що визначали особливості опіки та освіти осіб із обмеженнями життєдіяльності, а відтак безпосередньо впливали на становлення системи підготовки спеціальних учителів у США. Сучасний зміст та організація підготовки вчителів спеціальної освіти та інклюзивного навчання в США відповідають кодексу етичної поведінки спеціального вчителя, стандартам професійної діяльності та стандартам підготовки, перепідготовки й сертифрікації вчителів спеціальної освіти відповідно до їхньої спеціалізації.

Ключові слова: стандарти підготовки вчителів спеціальної освіти у США, підготовка вчителів спечіальної освіти та інклюзивного навчання, підготовка спеціальних учителів у США, кодекс етичної поведінки вчителя спеціальної освіти, стандарти продесійної діяльності вчителя спечіальної освіти, стандарти сертифікації вчителів спеціальної освіти, компаративістика. 